\title{
Lung Tissue
}

National Cancer Institute

\section{Source}

National Cancer Institute. Lung Tissue. NCI Thesaurus. Code C33024.

Tissue consisting of an external serous coat, subserous areolar tissue and lung parenchyma. The parenchyma is made up of lobules wound together by connective tissue. A primary lobule consists of a terminal bronchiole, respiratory bronchioles, and alveolar ducts, which communicate with many alveoli, each alveolus being surrounded by a network of capillary blood vessels. 